\title{
THEORETICAL ANALYSIS OF TRANSCRITICAL CARBON DIOXIDE VAPOR COMPRESSION CYCLE
}

\section{B. Saleh}

Mechanical Engineering Department, Faculty of Engineering, Assiut University, Assiut, Egypt.

(Received November 25, 2006 Accepted December 23 ,2006)

In the transcritical carbon dioxide vapor compression cycle heat is rejected in a gas cooler at supercritical pressure. At supercritical heat rejection the refrigerant temperature and pressure are independent on each other and one of the most important parameters affect on cycle performance is the pressure on the heat rejection side called the high pressure.

A theoretical analysis shows the effect of high pressure, superheat, evaporator and gas cooler exit temperature, and gas cooler exit temperature approach on performance of a transcritical carbon dioxide vapor compression cycle was investigated in this study.

The study defines an optimal high pressure which gives a maximum coefficient of performance and suggests that the cycle should operate at or near its optimal high pressure in order to keep its maximum coefficient of performance. The high pressure will also affect the cooling capacity and this effect can be used for boosting capacity at high ambient temperatures.

The effect of gas cooler exit temperature and compressor inlet temperature on the optimal high pressure also was investigated.

The study shows that the optimum high pressure is mainly a function of gas cooler exit temperature and compressor inlet temperature, while the value of the maximum coefficient of performance is dependent on the gas cooler exit and evaporating temperature. The study also indicates that the superheat of the gas at compressor inlet will have a positive effect on the coefficient of performance when operating with high heat rejection pressure at high ambient temperatures with high evaporating temperatures.

KEYWORDS: Carbon dioxide, transcritical cycle, cycle performance, natural refrigerant.

\section{INTRODUCTION}

Around the end of the $19^{\text {th }}$ century, carbon dioxide $\left(\mathrm{CO}_{2}-\mathrm{R} 744\right)$ was already employed as a refrigerant. However, when synthetic chlorofluorocarbons (CFCs) and 
Hydro chlorofluorocarbons (HCFCs) refrigerants came into use, $\mathrm{CO}_{2}$ use as a refrigerant began its decline. Due to ozone depletion potential (ODP) of CFCs and HCFCs refrigerants, the Montreal Protocol (1987) and its amendments have put in place a timetable to phase out the production of these refrigerants. As a result, hydrofluorocarbons (HFCs) have been introduced as alternative refrigerants due to their zero ODP. The HFCs refrigerants that were once expected to be acceptable permanent replacement refrigerants are now on the list of regulated substances because they have relatively large global warming potential (GWP) compared with natural fluids. This negative impact on global environment has led to an increased interest in natural fluids as refrigerants with $\mathrm{CO}_{2}$ receiving a significant consideration as a possible alternative refrigerant [1-4].

$\mathrm{CO}_{2}$ has very low environmental impact with zero ODP and negligible GWP. Against its poor thermodynamic properties with reference to the energy efficiency of a traditional vapor compression cycle, $\mathrm{CO}_{2}$ has excellent transport properties and very good properties related to heat transfer. Moreover, it is non toxic, non flammable, compatible with the most common materials and oils used in the refrigeration technology, and cheap. During the last few years there have been many studies, which show that the coefficient of performance (COP) of a real $\mathrm{CO}_{2}$ cycle is higher than that of cycles using conventional working fluids [5-9]. $\mathrm{CO}_{2}$ is seen today as one of the most promising refrigerants from ecological and economical aspects. It has been reintroduced as a refrigerant in many applications. Such applications include mobile and residential air conditioning systems and heat pump systems for dairy applications. In the later system simultaneous cooling at $4{ }^{\circ} \mathrm{C}$ and heating at $73{ }^{\circ} \mathrm{C}$ are required [7].

The thermodynamic properties and characteristics of $\mathrm{CO}_{2}$ are quite different from those of refrigerants used in conventional vapor compression cycles. Its application is limited by its critical parameters (critical temperature, $\mathrm{T}_{\mathrm{c}}=31.1{ }^{\circ} \mathrm{C}$ and critical pressure, $\mathrm{P}_{\mathrm{c}}=7.38 \mathrm{MPa}$ ). The possibility to use $\mathrm{CO}_{2}$ beyond these limits in high temperature processes is given by the application of a transcritical process. In the transcritical process, the heat rejection pressure, often cited as the high pressure, is about 7.4-12.0 MPa and the absorbing heat pressure is about 2.0-6.0 MPa. The system will then use a transcritical cycle that operates partly below and partly above the critical pressure. The pressure level in the system will be quite high, a benefit of high pressure is the $80-90 \%$ smaller compressor displacement needed for a given capacity. Compressor pressure ratios are low, thus giving favorable conditions for high compressor efficiency [10]. At supercritical pressure, the refrigerant temperature glide during heat rejection is large. The heat transfer from the refrigerant takes place by cooling the compressed gas and no condensation happens. The heat rejecting heat exchanger is then called gas cooler instead of condenser. Gliding temperature can be useful in heat pumps for heating water or air. With proper heat exchanger design the refrigerant can be cooled to a few degrees above the entering coolant (air, water) temperature, and this contributes to high COP of the system [11].

Sarkar et al. [7] performed a comparative performance characteristic of four natural refrigerants, $\mathrm{CO}_{2}$, ammonia, propane and isobutane for subcritical/transcritical high temperature heat pump applications. Rozhentsev and Wang [12 ] made a cycle analysis of a $\mathrm{CO}_{2}$ air conditioner and showed that the effect of internal superheating caused by the compressor motor on the system COP is very small while the compressor efficiency and gas cooler temperature approach have a significant effect. Huff et al. 
[13] studied three different variations of a two-stage transcritical $\mathrm{CO}_{2}$ vapor compression cycles using simplified modeling assumptions. All two-stage systems investigated show significant potential for performance improvement. Yang et al. [9] investigated three different variations of a transcritical $\mathrm{CO}_{2}$ two-stage compression cycles. Yitai et al. [14] discussed the application of $\mathrm{CO}_{2}$ transcritical cycle heat pump drying system and analyzes the influence of evaporation temperature, superheat of compressor inlet and outlet temperature of the gas cooler on the drying system performance. Jiangping et al. [15] introduced a development of $\mathrm{CO}_{2}$ automotive air conditioning (AAC) system. $\mathrm{CO}_{2}$ refrigeration cycle was optimized based on the characteristics of $\mathrm{CO}_{2}$ transcritical cycle. They developed a domestic $\mathrm{CO}_{2}$ system prototype and test bench. The result was acceptable and $\mathrm{CO}_{2} \mathrm{AAC}$ prototype presented good refrigerant performance in the test.

The performance of $\mathrm{CO}_{2}$ system in transcritical cycle will not be exactly the same as the conventional subcritical systems. Hence, simulation models developed for the conventional subcritical systems cannot be employed for this system. Therefore, there is still need for more system simulation studies as experimental performance evaluation is difficult, face a lot of problems, and expensive.

In this study a theoretical cycle analysis showing the effect of high pressure, superheat, evaporating and gas cooler exit temperature, and gas cooler exit temperature approach on the cycle performance was investigated.

\section{NOMENCLATURE}

\begin{tabular}{|c|c|c|c|}
\hline CFCs & chlorofluorocarbons & HFCs & hydrofluorocarbons \\
\hline $\mathrm{COP}$ & coefficient of performance & ODP & ozone depletion potentia \\
\hline $\mathrm{CO}_{2}(\mathrm{R} 744)$ & carbon dioxide & $\mathrm{P}$ & pressure, $\mathrm{MPa}$ \\
\hline GWP & global warming potential & $\mathrm{S}$ & specific entropy, kJ $/ \mathrm{kg} . \mathrm{K}$ \\
\hline $\mathrm{h}$ & specific enthalpy, $\mathrm{kJ} / \mathrm{kg}$ & $\mathrm{T}$ & temperature, ${ }^{\circ} \mathrm{C}$ \\
\hline HCFCs & hydrochlorofluorocarbons & $\mathrm{W}$ & specific work, $\mathrm{kJ} / \mathrm{kg}$ \\
\hline \multicolumn{4}{|l|}{ Greek } \\
\hline$\eta$ & efficiency & & \\
\hline \multicolumn{4}{|l|}{ Subscripts } \\
\hline $\mathrm{a}$ & actual & Gc & gas cooler \\
\hline $\mathrm{amb}$ & ambient & Is & isentropic \\
\hline app & approach temperature & opt & Optimum \\
\hline c & critical & sup & Superheat \\
\hline $\mathrm{e}$ & evaporator & $1, \ldots, 4$ & cycle points \\
\hline hp & high pressure & & \\
\hline
\end{tabular}

\section{CYCLE ANALYSIS AND SIMULATION}

Consider a simple transcritical $\mathrm{CO}_{2}$ system including a compressor, a gas cooler, a throttling valve, and an evaporator as shown in Fig. 1-a. The corresponding pressure-specific enthalpy ( $p-h)$ diagram (see Fig. 1-b) indicates that such transcritical $\mathrm{CO}_{2}$ cycle consists of compression process (1-2a) with an isentropic efficiency 
$\eta_{i s}$, an isobaric heat rejection process (2a-3), a constant enthalpy expansion process

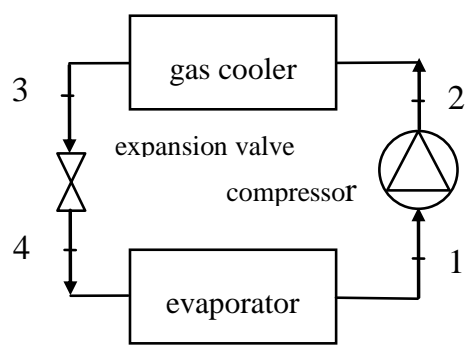

(a)

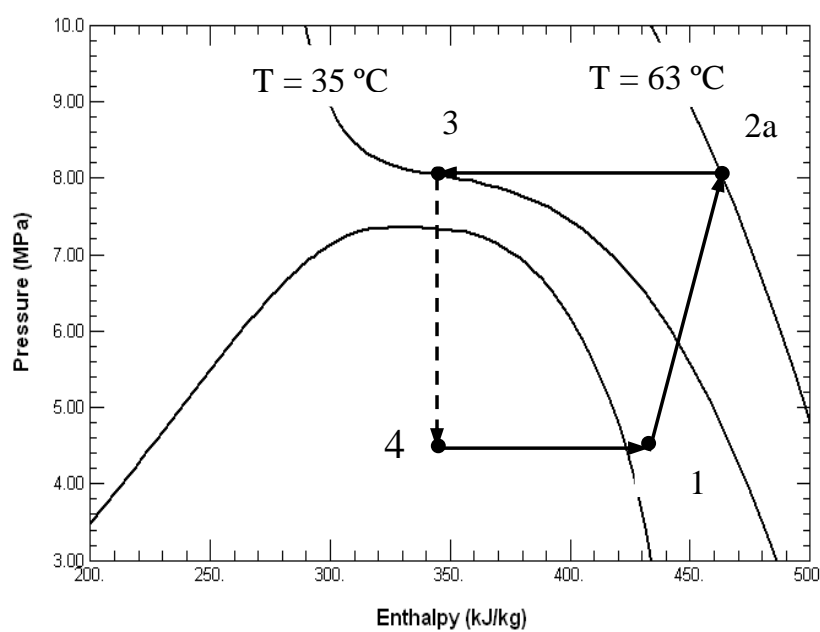

(b)

Fig. 1. Schematic of a transcritical $\mathrm{CO}_{2}$ cycle (a) and pressure enthalpy diagram (b).

(3-4), and an isobaric evaporation process (4-1). By using the numbers in Fig. 1, a steady state energy balance for each cycle component is presumed and analysis of the cycle performance is described as follows:

A specific cooling effect, $q_{e}$

$q_{e}=\left(h_{1}-h_{4}\right)$

A specific heat load of the gas cooler, $q_{g c}$ :

$q_{g c}=\left(h_{2 a}-h_{3}\right)$

Actual work of the compressor, $w_{a}$ :

$w_{a}=\left(h_{2 a}-h_{1}\right)=\left(h_{2 i s}-h_{1}\right) / \eta_{i s}$

The coefficient of performance (COP) of this cycle is defined as:

$\mathrm{COP}=\frac{q_{e}}{w_{a}}=\frac{\left(h_{1}-h_{4}\right) \eta_{i s}}{\left(h_{2 i s}-h_{1}\right)}$

Where $h_{1}, h_{2 a}, h_{3}$, and $h_{4}$ denote the specific enthalpies of $\mathrm{CO}_{2}$ at the corresponding points shown in Fig. 1, and $\eta_{i s}$ represents the isentropic compression efficiency. The thermodynamic properties of $\mathrm{CO}_{2}$ for the cycle performance analysis have been calculated by REFPROP 7 software [16] that use equation of state from reference [17]. A simulation computer program has been used for the cycle analysis. 
As can be seen from the $35^{\circ} \mathrm{C}$ isotherm of the $\mathrm{CO}_{2}$ cycle diagram of Fig. 1-b, the change of enthalpy is less pronounced at lower and higher pressures. Thus, the COP peaks at a specific high pressure called optimum high pressure $\left(\mathrm{P}_{\mathrm{opt}}\right)$. Furthermore, as illustrated from the isotherms $\left(35^{\circ} \mathrm{C}\right.$ and $\left.63{ }^{\circ} \mathrm{C}\right)$ of Fig. 1-b, change of enthalpy is comparatively less for a further increase of ambient temperature. As a result, one can expect the maximum value of COP to be less pronounced as the ambient temperature is increased further.

In Figs. 2 and 3, the $\mathrm{CO}_{2}$ transcritical cycle is shown in a pressure enthalpy and a temperature-entropy ( $\mathrm{T}$-s) diagrams for three different high pressures 8, 9.3 and 10.5 $\mathrm{MPa}$. For the three cycles the evaporating temperature is $10^{\circ} \mathrm{C}$ with $5 \mathrm{C}$ superheat, ambient temperature of $35^{\circ} \mathrm{C}$ and $3 \mathrm{C}$ approach temperature difference between gas cooler refrigerant outlet and coolant inlet temperature. It is seen that the required compression work increases with increasing high pressure. It is also noted from Fig. 2 that as the high pressure is increased, the cooling effect is increased with large rate for lower high pressures but increased with relatively lower rate when the high pressure reaches a certain value and this is due to the shape of the isotherm. Moreover, it is evident that there is an optimal high pressure which gives a maximum COP. This result suggests that it is desirable that a transcritical $\mathrm{CO}_{2}$ system should operate at or near its optimal high pressure to keep its maximum COP.

In the numerical example shown in Figs. 2 and 3, the optimum high pressure is 9.3 MPa which will give the highest cooling COP at these conditions. The pressure enthalpy diagram shows that going from 8 to $9.3 \mathrm{MPa}$ dramatically increases the specific cooling capacity with only moderate increase in the compressor specific work. While going from 9.3 to $10.5 \mathrm{MPa}$, the compressor work increases more than the cooling capacity.

\section{RESULTS AND DISCUSSION}

\subsection{Effect Of The High Pressure}

In Fig. 4 the cooling COP is shown as a function of the high pressure for ambient temperatures ranging from $+25^{\circ} \mathrm{C}$ to $+50{ }^{\circ} \mathrm{C}$ (the gas cooler exit temperatures ranging from $+28{ }^{\circ} \mathrm{C}$ to $+53{ }^{\circ} \mathrm{C}$ ). The evaporating temperature is $+10{ }^{\circ} \mathrm{C}$ with $5 \mathrm{C}$ superheat, $75 \%$ constant compressor isentropic efficiency, and $3 \mathrm{C}$ gas cooler exit temperature approach. Pressure drop is neglected to simplify the presentation.

Several conclusions can be drawn from Fig. 4. First, when the air inlet temperature (ambient temperature) entering the gas cooler increases the $\mathrm{CO}_{2}$ exit temperature also increases so the high pressure needs to be increased in order to maximize cycle COP in transcritical operation. This maximum COP decreases as the ambient temperature increases. This shows that it is the $\mathrm{CO}_{2}$ exit temperature from the gas cooler that determines the optimum high pressure (in addition to the compressor inlet temperature). Second, the COP curve tends to be flatter when the ambient temperature is higher. And third, the COP curve is not symmetric along the pressure axis. At lower ambient temperatures, the COP drops more steeply on the low-pressure values than on the high-pressure values. So, accurate high pressure control is more important for maximizing COP on cold days than for the case of hotter days. 


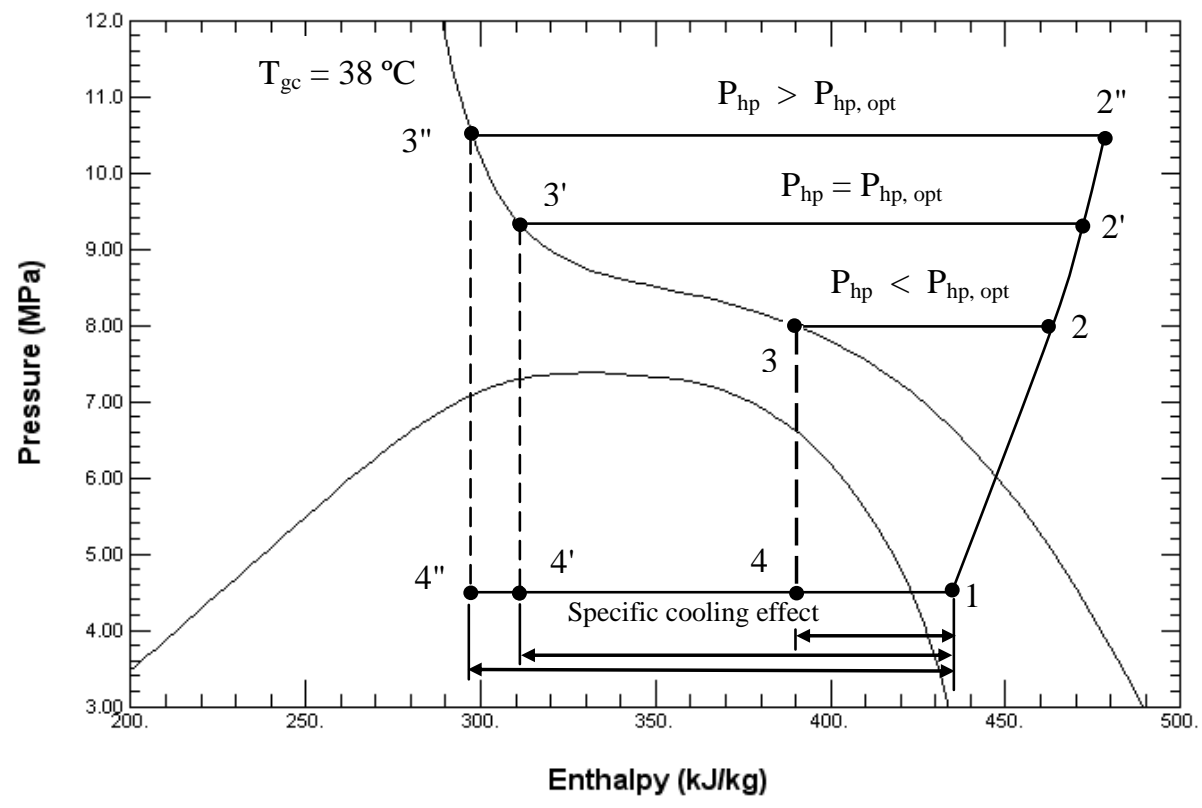

Fig. 2. Transcritical $\mathrm{CO}_{2}$ cycle at three different high pressures $8,9.3$ and $10.5 \mathrm{MPa}$ in a pressure-enthalpy diagram. Evaporating temperature $+10{ }^{\circ} \mathrm{C}, 5 \mathrm{C}$ superheat and $38^{\circ} \mathrm{C}$ gas cooler exit temperature.

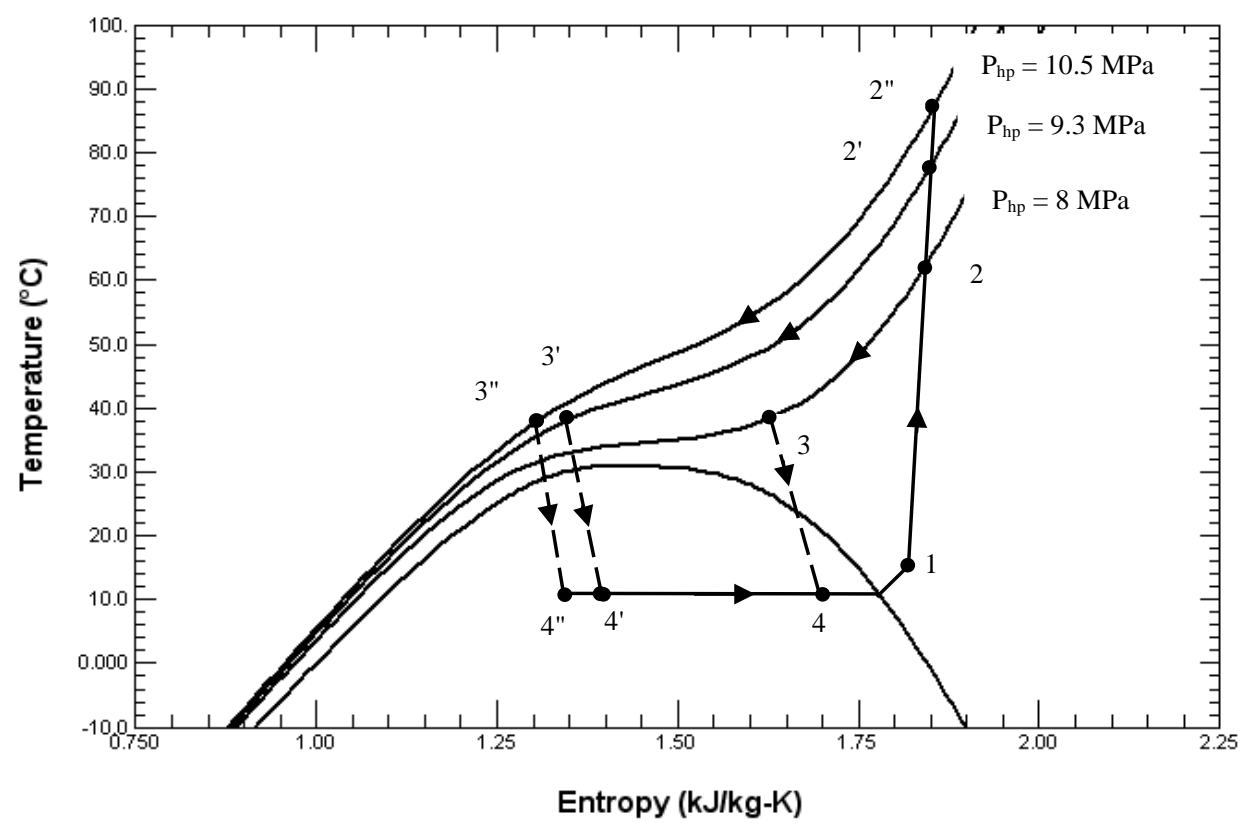

Fig. 3. Transcritical $\mathrm{CO}_{2}$ cycle at three different high pressures $8,9.3$ and $10.5 \mathrm{MPa}$ in a temperature-entropy diagram. Evaporating temperature $+10{ }^{\circ} \mathrm{C}, 5 \mathrm{C}$ superheat and $38^{\circ} \mathrm{C}$ gas cooler exit temperature. 


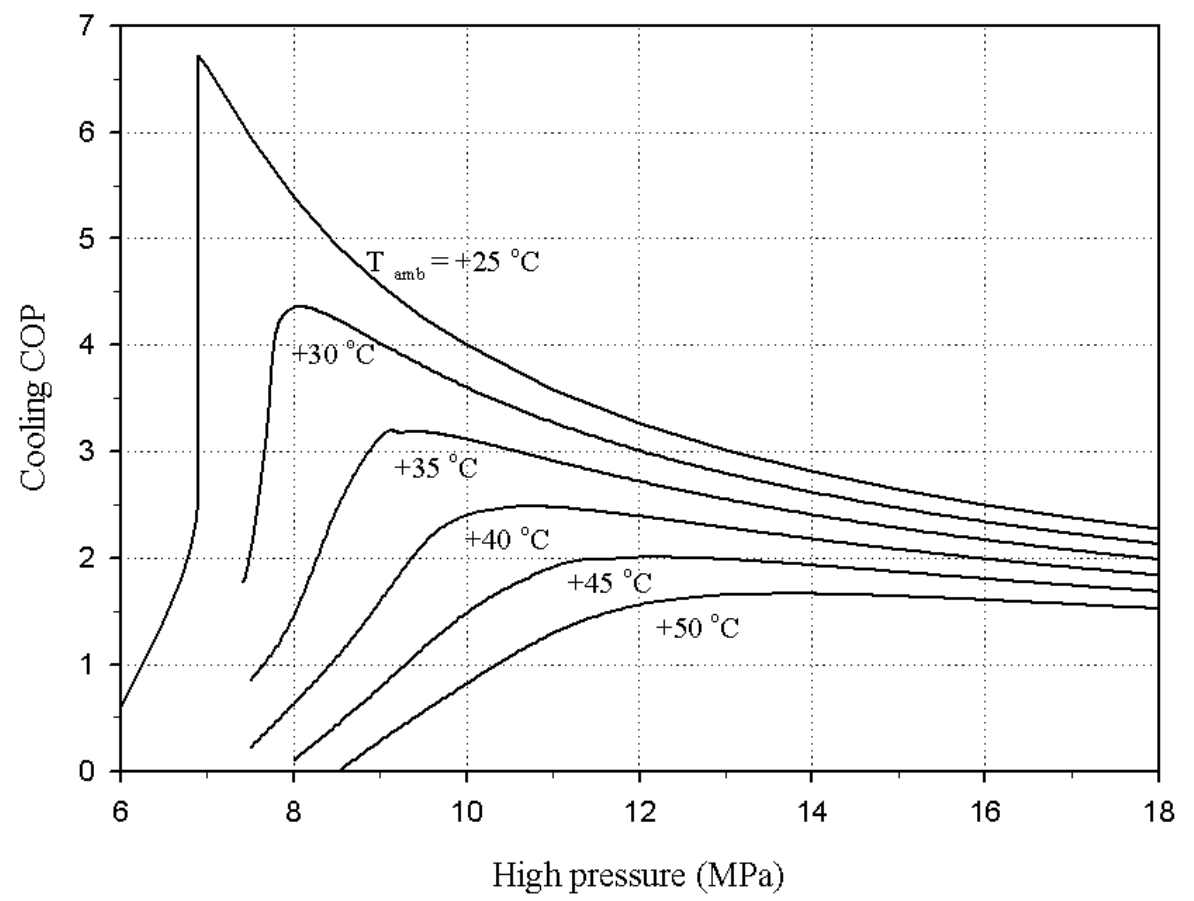

Fig. 4. Cooling Coefficient of performance (COP) at varying high pressure at ambient temperature ranging from $+25{ }^{\circ} \mathrm{C}$ to $+50{ }^{\circ} \mathrm{C}$, gas cooler exit temperature approach of $3 \mathrm{C}$ and $75 \%$ compressor isentropic efficiency.

At low ambient temperatures, the $\mathrm{CO}_{2}$ gas cooler exit temperature can be below the critical temperature. The optimum high pressure is then in most cases the saturation pressure. For example, at ambient temperature $\mathrm{T}_{\mathrm{amb}}=25^{\circ} \mathrm{C}$ and the gas cooler exit temperature approach is $3 \mathrm{C}, \mathrm{CO}_{2}$ gas cooler exit temperature is $28^{\circ} \mathrm{C}$, the optimum high pressure is $6.9 \mathrm{MPa}$ which is the saturation pressure at $28^{\circ} \mathrm{C}$. Only with gas cooler exit temperatures very close to critical temperature it will be advantageous to raise the pressure above the saturation pressure.

The maximum COP and corresponding high pressure are plotted for each ambient temperature in Fig. 5. If diagrams like the ones in Fig. 5 are made for various evaporating temperatures with varying degree of superheat, the combined diagrams shown in Fig. 6 result, which shows how the optimum high pressure is lowered when the evaporating temperature and superheat increases.

In Figs. 6 and 7, the optimum high pressure curves and the corresponding maximum COP are plotted for $-10,0,+10$, and $+20{ }^{\circ} \mathrm{C}$ evaporating temperature without superheating. In addition, the curves for $+10^{\circ} \mathrm{C}$ evaporating temperature with $10 \mathrm{C}$ superheat and $+20^{\circ} \mathrm{C}$ evaporating temperature with $20 \mathrm{C}$ superheat are included. 


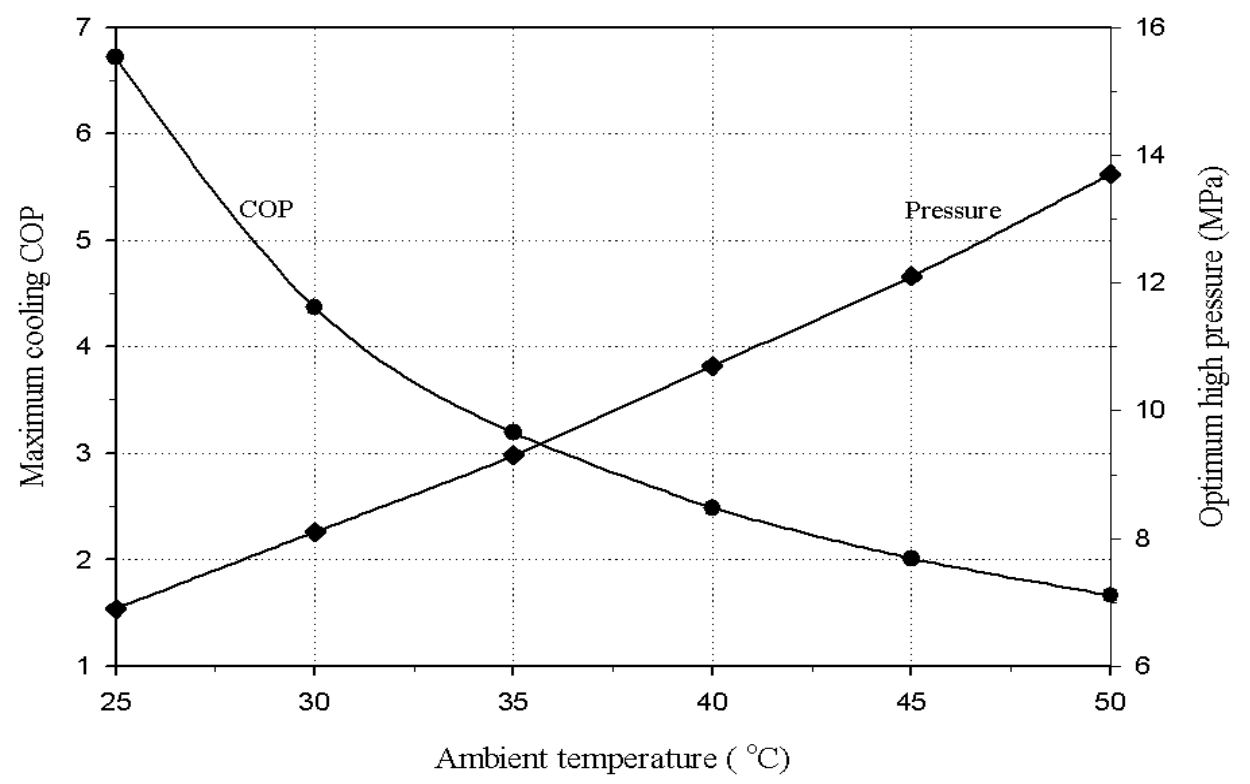

Fig. 5. Optimum high pressure and corresponding maximum $\mathrm{COP}$ at various ambient temperature for evaporating temperature $+10{ }^{\circ} \mathrm{C}$ with $5 \mathrm{C}$ superheat and $3 \mathrm{C}$ gas cooler outlet temperature approach and $75 \%$ compressor isentropic efficiency.

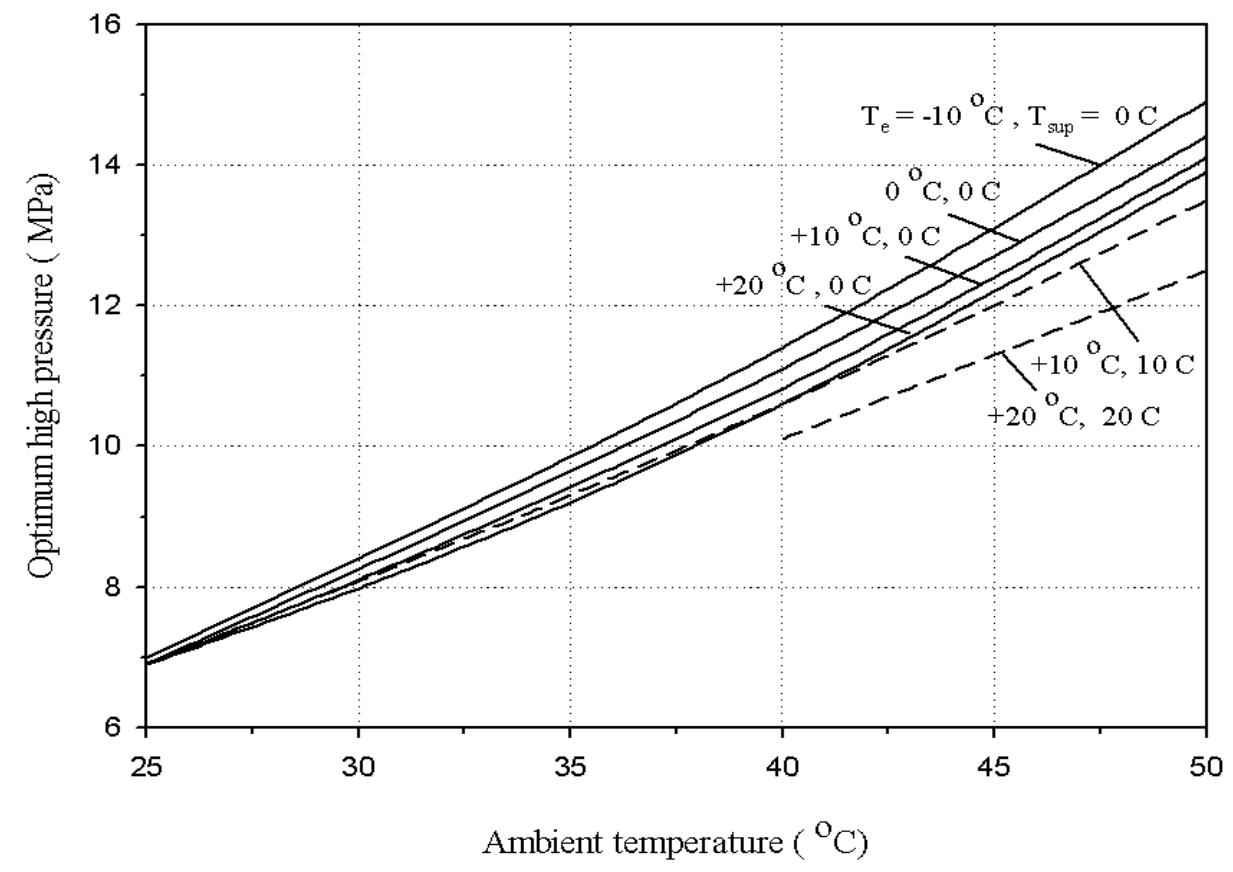

Fig. 6. Optimum high pressure at varying evaporating temperature and compressor inlet superheat with $3 \mathrm{C}$ gas cooler temperature approach and $75 \%$ compressor efficiency. 


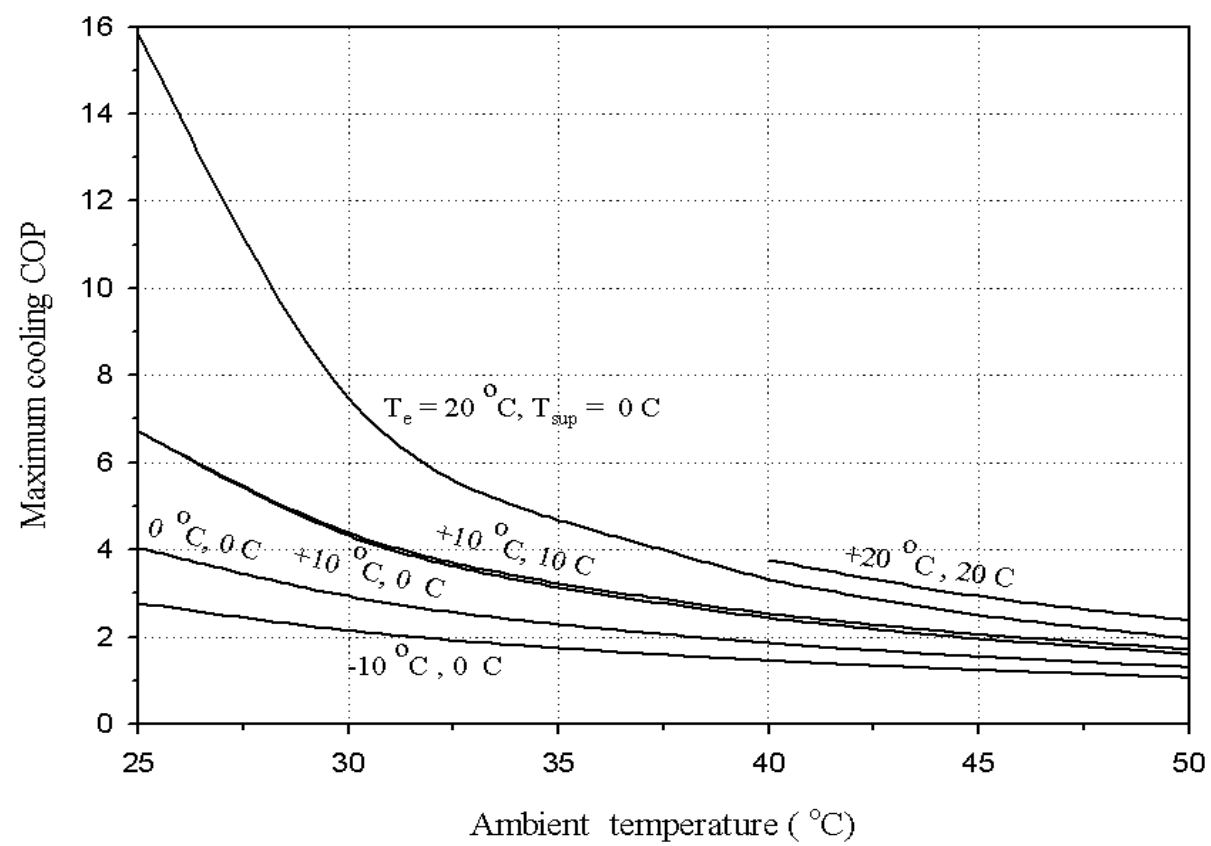

Fig. 7. Maximum cooling COP for varying evaporating temperature and compressor inlet superheat with $3 \mathrm{C}$ gas cooler temperature approach and $75 \%$ compressor efficiency.

Fig. 6 shows how the optimum high pressure decreases with increasing evaporating temperature. It also indicates how superheat further decreases the optimum high pressure. At $+10^{\circ} \mathrm{C}$ evaporating temperature and $10 \mathrm{C}$ superheat, the optimum high pressure is lower than that at $+10{ }^{\circ} \mathrm{C}$ with no superheat. Fig. 7 shows that the value of the maximum $\mathrm{COP}$ is in most cases determined only by the evaporating temperature (in addition to the gas cooler exit temperature). Only at $+20{ }^{\circ} \mathrm{C}$ evaporating temperature, a significant improvement of maximum COP can be obtained by introducing superheat.

The positive effect of superheat from Fig. 7 is generally true in cases with high ambient temperature and high evaporating temperature, which prevails in airconditioning units. At low ambient temperatures, or sub-critical condensation, the superheat has a negative effect on the COP. The reason for this is that below a certain $\mathrm{CO}_{2}$ gas cooler exit temperature, the relative increase in specific work is larger than the relative increase in specific cooling effect.

The gas cooler temperature approach was assumed to be constant for each high pressure and ambient temperature. In a real system the gas cooler approach temperature for a given heat exchanger will be higher at low high pressure due to the thermophysical properties of $\mathrm{CO}_{2}$, pushing the optimum high pressure up at low ambient temperatures giving a less linear behavior in this region. The corresponding maximum COP will decrease compared to the curve in Fig. 5. At high ambient temperatures, where the optimum high pressure is high, the isentropic compressor efficiency will in many cases drop due to higher pressure ratios thus reducing the 
optimum high pressure at high ambient temperatures due to increased compressor work. In this analysis the compressor isentropic efficiency is assumed to be constant.

Another observation from Fig. 6 is that the optimum high pressure for $+10{ }^{\circ} \mathrm{C}$ evaporating temperature with $10 \mathrm{C}$ superheat almost overlaps the curve for $+20^{\circ} \mathrm{C}$ evaporating temperature without superheat. This shows that it is the compressor inlet (evaporating temperature and superheat) temperature that determines the optimum high pressure (in addition to the gas cooler exit temperature) as long as the compressor inlet superheat leads to increased specific cooling capacity, for instance by using an internal suction line heat exchanger. This is illustrated in Fig. 8 where three cycles having almost equal optimum high pressure are shown $(9.2,9.3$, and 9.4 $\mathrm{MPa}$ ). The actual value for the corresponding maximum $\mathrm{COP}$ is determined by the saturation temperature at the evaporator outlet with decreasing maximum COP for decreasing evaporating temperature. The maximum $\mathrm{COP}$ values are 4.68, 3.23, and 2.35 respectively.

\subsection{Effect Of Gas Cooler Exit Temperature Approach On The COP}

Finally the effect of the gas cooler approach temperature on the COP will be discussed. In the analysis a temperature approach of $3 \mathrm{C}$ between the inlet coolant temperature (water or air) and outlet $\mathrm{CO}_{2}$ temperature has been used. This is a realistic value for a well designed gas cooler operating at design point conditions. In Fig. 9 the effect on $\mathrm{COP}$ for approach temperatures ranging from 2 to $10 \mathrm{C}$ is shown. The diagram is for ambient temperature $+35^{\circ} \mathrm{C}$ with evaporating temperature $+10{ }^{\circ} \mathrm{C}, 5 \mathrm{C}$ superheat and $75 \%$ compressor isentropic efficiency. Considerable drops of COP are observed with the increase of approach temperatures. From Fig. 9, the maximum COP for larger approach temperatures has been shifted to higher value of high pressure. The diagram shows how the optimum high pressure increases from 9.0 to $11.3 \mathrm{MPa}$ while the maximum COP is reduced from 3.37 to $2.27(-33 \%)$ for change of approach temperature from $2 \mathrm{C}$ to $10 \mathrm{C}$.

In addition to the influence on COP, the high pressure will also affect the cooling capacity. As shown from Fig. 10 there is an optimum high pressure that gives a maximum cooling capacity. The symbols in Fig. 10 show the maximum cooling capacity values for each ambient temperature. The cooling capacity reaches the maximum value at a higher high pressure than the maximum COP. Increasing the high pressure will increase the cooling capacity at each ambient temperature and this effect can be used for boosting capacity at high ambient temperatures, as illustrated in Fig. 10 where the cooling capacity in watts. The diagram is for $10^{\circ} \mathrm{C}$ evaporating temperature with $5 \mathrm{C}$ superheat and $3 \mathrm{C}$ gas cooler temperature approach. The compressor inlet volume flow rate is $50 \mathrm{ccm} / \mathrm{s}$ with a linear drop in volumetric efficiency from $80 \%$ to $50 \%$ at pressure ratio between discharge and suction pressure of 1.5 and 4.0.

\section{CONCLUSION}

A theoretical thermodynamic cycle simulation of transcritical carbon dioxide $\left(\mathrm{CO}_{2}\right)$ vapor compression cycle has been presented in this study. Operating efficiency in terms of cooling coefficient of performance (COP) for a residential air conditioning application with moderate to high evaporating temperatures has been discussed. The 


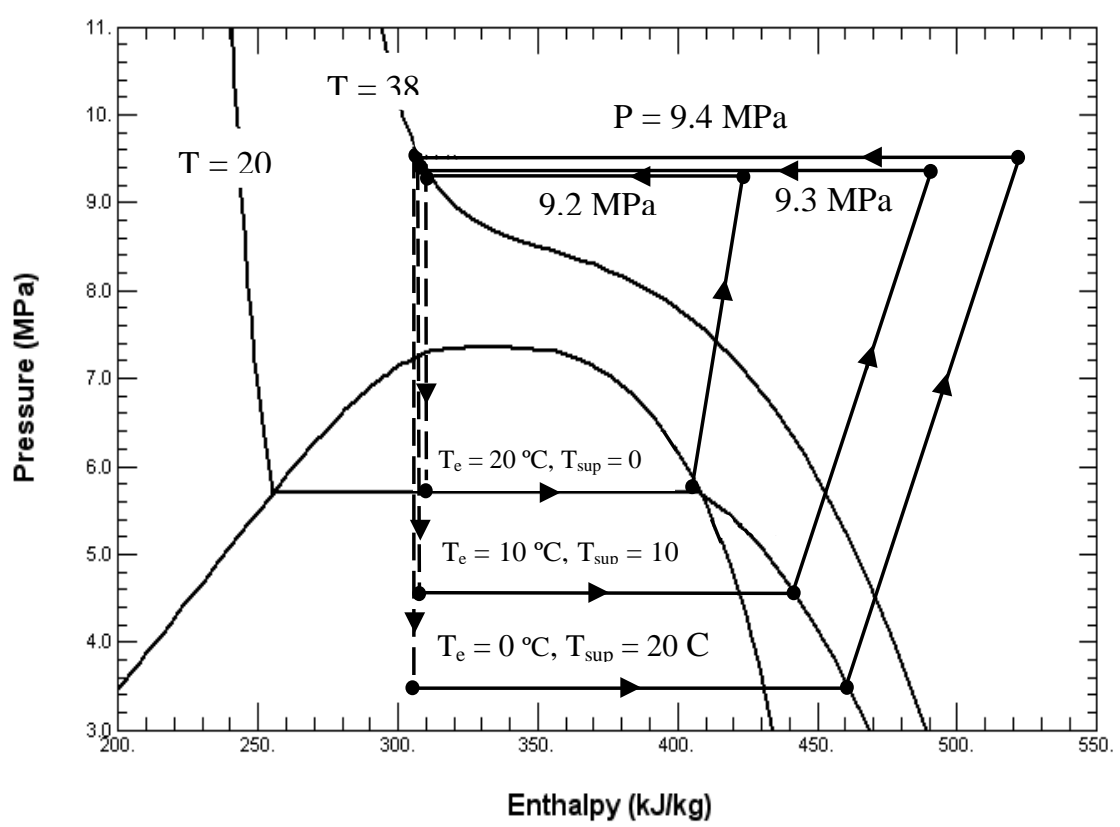

Fig. 8. Three equivalent cycles in terms of optimum high pressure.

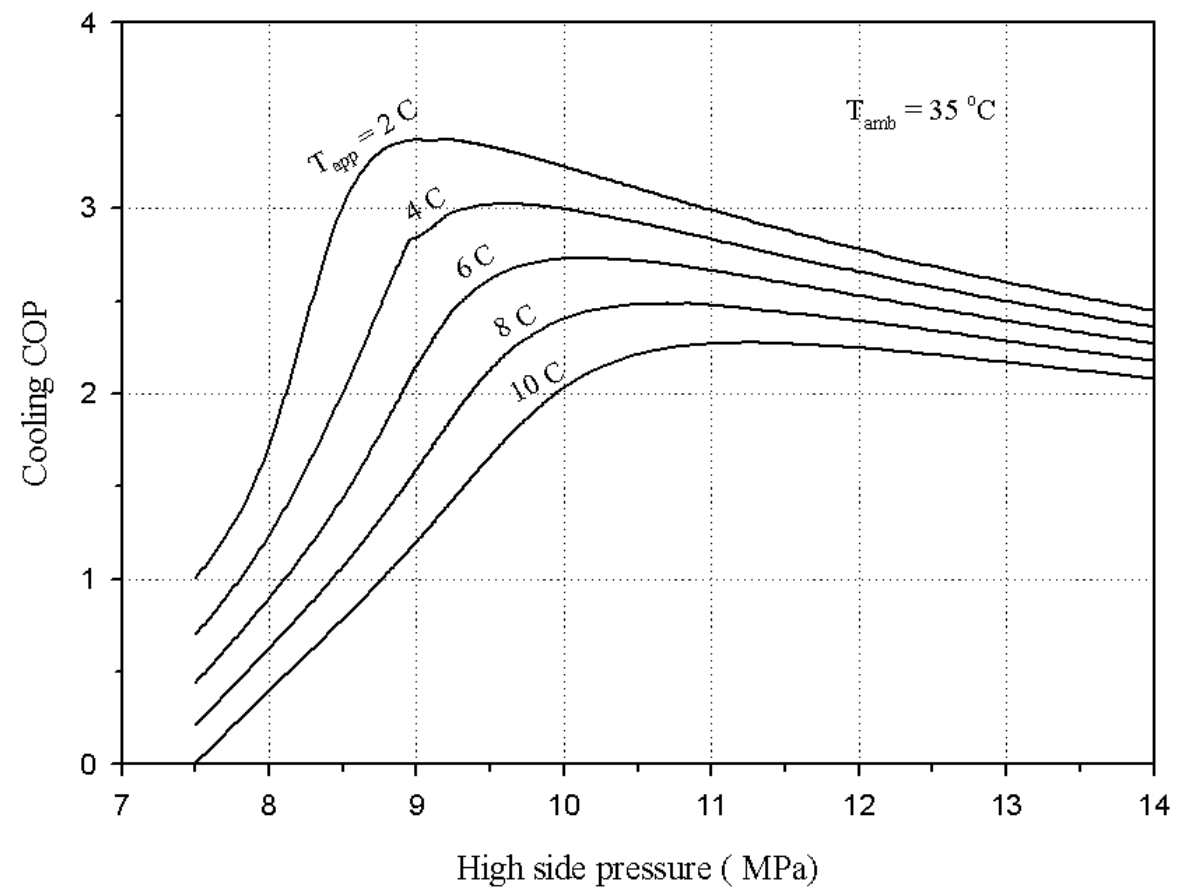

Fig. 9. The effect of gas cooler temperature approach on $\mathrm{COP}$ at varying high pressure at $+10{ }^{\circ} \mathrm{C}$ evaporating temperature with $5 \mathrm{C}$ superheat, $+35{ }^{\circ} \mathrm{C}$ ambient temperature and $75 \%$ compressor isentropic efficiency. 


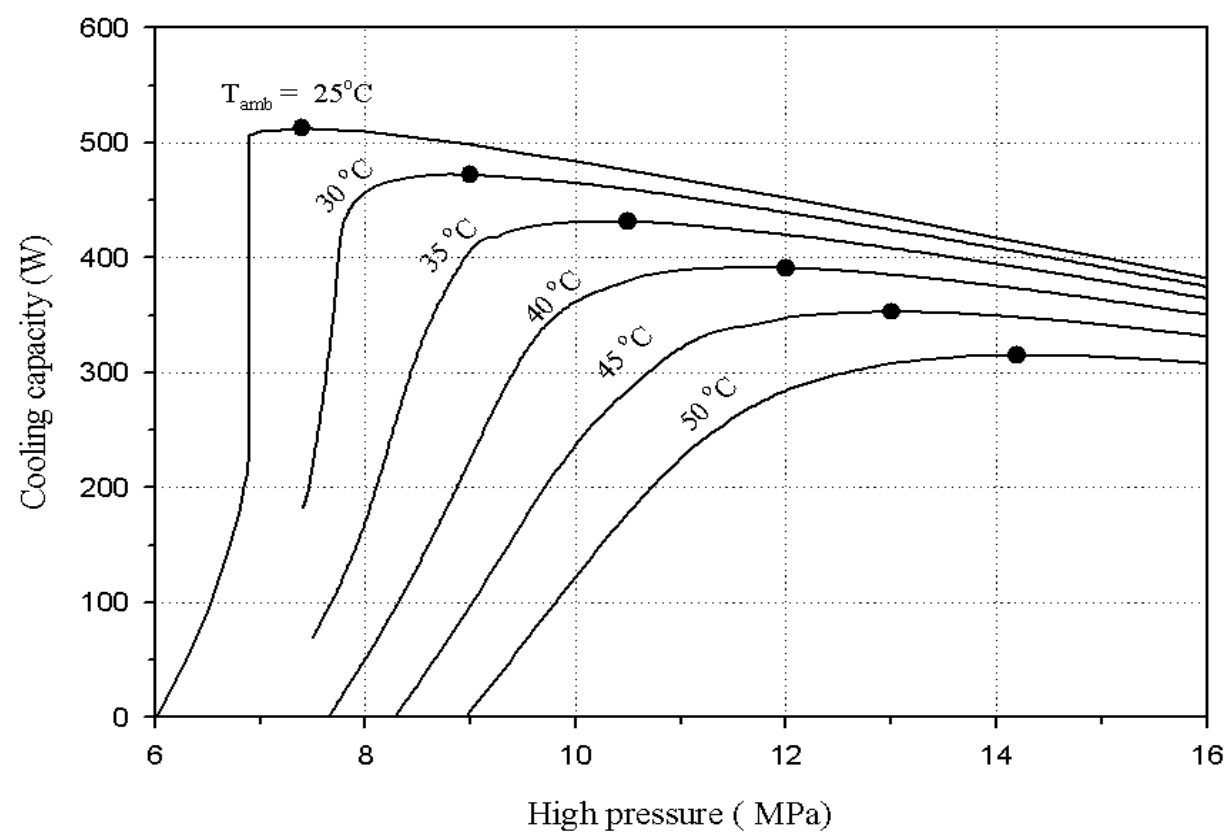

Fig. 10. Theoretical cooling capacity at varying high pressure.

effect of high pressure at different ambient temperature and at different gas cooler temperatures approach on COP is discussed. The effect of superheat to the compressor inlet is also discussed.

The study shows that for a transcritical $\mathrm{CO}_{2}$ cycle there is an optimal high pressure which gives a maximum COP and suggests that the cycle should operate at or near its optimum high pressure for maximizing cycle COP. The analysis reveals that the values of the optimal high pressure mainly depend on the outlet temperature of the gas cooler, and the compressor inlet temperature, while the COP values depend on gas cooler exit temperature and evaporating temperature. The results show that as the high pressure varies, both COP and refrigeration effect of the cycle will change.

Superheat of the gas at compressor inlet, either being superheated evaporator outlet controlled by a thermostatic expansion valve or as a result of a suction line heat exchanger, will have a positive effect on the COP when operating with high heat rejection pressure at high ambient temperatures with high evaporating temperatures.

\section{REFERENCES}

1. Cecchinato, L., Corradi, M., Fornasieri, E., and Zamboni, L. "Carbon dioxide as refrigerant for tap water heat pumps: A comparison with the traditional solution", I. J. Refrigeration, 28, 1250-1258, 2005.

2. Brown, J. S., and Domanski P. A., "Semi-theoretical simulation model for a transcritical carbon dioxide model A/C system", SAE 2000 World Congress Proceeding, Society of Automotive Engineers, Inc. (ASE). SAE Technical paper 
series 2000-01-0985, March 6-9, 2000, Detroit, MI, Society of Automotive Engineers, Inc., Warrendale, PA, pp 1-11, 2000.

3. Kim, M., Pettersen, J., Bullard, C.W. "Fundamental process and system design issues in $\mathrm{CO}_{2}$ vapor compression systems", Progress in Energy and Combustion Science 30, 119-174, 2004.

4. Abdel-Rahim, Y. M. "Generalized A/C and H/P transcritical R744 compressor performance in wet and dry regions", Proceeding of 2004 Solar conference, July 11- 14, Portland, Oregon USA, pp 1 - 8, 2004.

5. Koecker, K., Schmid, E. L., Steimle, F. "Carbon dioxide as a working fluid in drying heat pumps", I. J. Refrigeration, 24, 100-107, 2001.

6. Chen, Y., Lundqvist, P., Johansson, A., Platell, P. "A comparative study of the carbon dioxide transcritical power cycle compared with an organic rankine cycle with R123 as working fluid in waste heat recovery", Applied Thermal Engineering, 26, 2142-2147, 2006.

7. Sarkar, J., Bhattacharyya, S., and Gopal, M. R. "Simulation of a transcritical CO2 heat pump cycle for simultaneous cooling and heating applications" I. J. Refrigeration, 29, 735-743, 2006.

8. Sarkar, J., Bhattacharyya, S., and Gopal, M. R. "Natural refrigerant and transcritical cycles for high temperature heating", I. J. Refrigeration, 2006, Article in press.

9. Yang, J. L., Ma, Y. T., and Liu, S. C. "Performance investigation of transcritical $\mathrm{CO}_{2}$ two-stage compression cycles with expander", Energy, 2006, Article in press.

10. Pettersen, J. "Comparison of explosion energies in residential air-conditioning systems based on HCFC-22 and $\mathrm{CO}_{2}$ ", $20^{\text {th }}$ international congress of refrigeration (IIR), Sydney, Australia, September 19-24, 1999.

11. Neksa, $\mathrm{P}$. " $\mathrm{CO}_{2}$ as refrigerant for systems in transcritical operation, principles and technology status”, AIRAH's 2004 natural refrigerant conference, Sydney, July 28, pp 28-32, 2004.

12. Rozhentsev, A., Wang, C. "Some design feature of a CO2 air conditioner", Applied thermal Engineering, 21, 871-880, 2001.

13. Huff, H., Hwang, Y., and Radermacher, R. "Options for two-stage transcritical carbon dioxide cycle", The $5^{\text {th }}$ IIR-Gustav Lorentzen conference on natural working fluids, September 17-20, Guangzhou, China, pp. 159-164, 2002.

14. Ma, Y., Li, M., Lu, W., and Wang, J. "The influence of characteristics of $\mathrm{CO}_{2}$ transcritical cycle on the heat pump drying system", The $5^{\text {th }}$ IIR-Gustav Lorentzen conference on natural working fluids, September 17-20, China, pp. 173-178, 2002.

15. Chen, J., Mu, J., Lui, J., Niu, Y., and Chen, Z. "Development of the transcritical $\mathrm{CO}_{2}$ automotive air-conditioning system", The $5^{\text {th }}$ IIR-Gustav Lorentzen conference on natural working fluids, September 17-20, China, pp.47-52, 2002.

16. Leommon, E. W., McLinden M. O., and Huber M. L. NIST reference fluid thermodynamic and transport properties-REFPROP. NIST standard reference database 23 - Version 7.0, 2002. 
17. Span, R., and Wagner, W. "A New Equation of State for Carbon Dioxide Covering the Fluid Region from the Triple-Point Temperature to $1100 \mathrm{~K}$ at Pressures up to 800 MPa”, J. Phys. Chem. Ref. Data, 25, 1509-1596, 1996.

\section{تحليل نظري لاورة ضغط البخار باستخدام ثاني أكسيد الكريون فيما بعد النقطة الحرجة}

في دورة ضغط البخار باستخدام ثاني أكسيد الكربون فيما بعد النقطة الحرجة يتم طرد الحرارة في

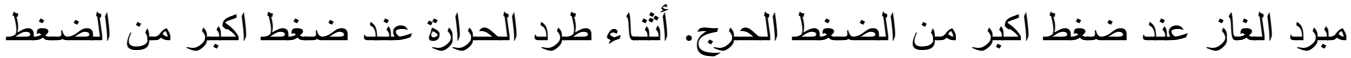
الحرج تعتبر خاصيتا ضغط و درجة حرارة مائع التبريد مستقلتان عن بعضهما البعض. و يعتبر الضغط أحد أهم العوامل التي تؤثر علي أداء الدورة و بطلق علية الضغط العالي.

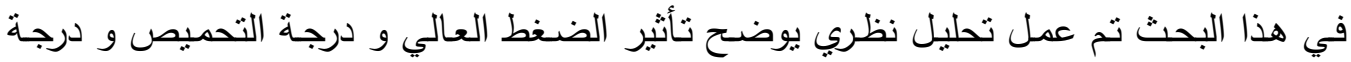
حرارة المبخر و درجة حرارة خروج مائع التبريد من مبرد الغاز و فرق درجات الحرارة بين الوسبط المبرد ( هواء ) و مائع التبريد (ثاني أكسيد الكربون ) عند خروجه من مبرد الغاز علي معامل أداء دورة ضغط البخار باستخدام ثاني أكسيد الكربون فيما بعد النقطة الحرجة.

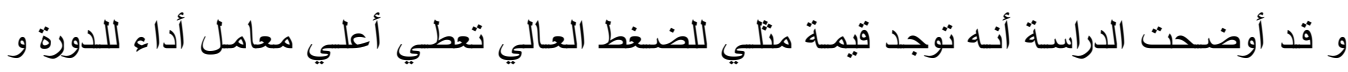

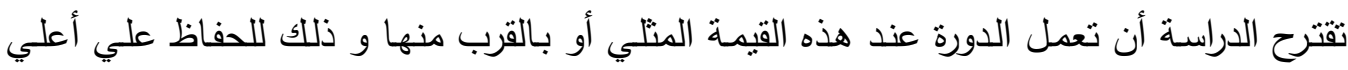

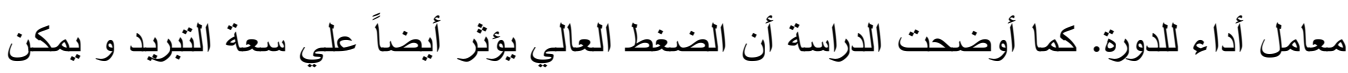
أن بستخدم هذا التأثير لزيادة سعة التبريد عند درجات حرارة الجو المرتفعة.

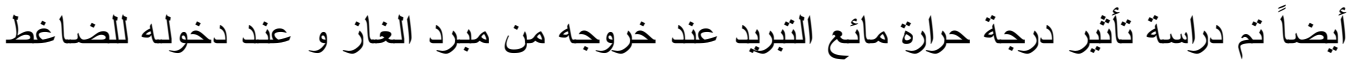

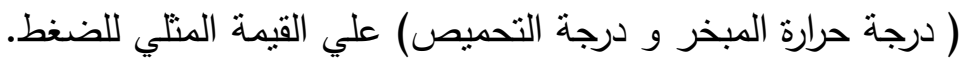
و قد بينت الدراسة أن القيمة المنلي للضغط العالي تعتمد علي كل من درجة حرارة مائع التبريد عند خروجه من مبرد الغاز و عند دخوله للضـاغط بينما بعتمد معامل الأداء علي درجة حرارة

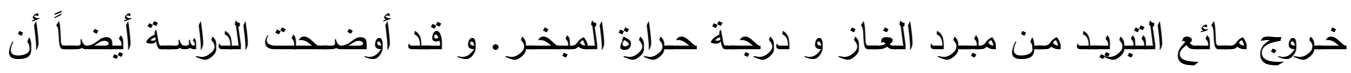
تحميص مائع التبريد الداخل للضـاغط لـه تأثثر إيجابي علي معامل الأداء عندما تكون درجـة حرارة الجو مرتفعة باستخدام قيم مرتفعة للضغط العالي و درجة حرارة تبخير عالية. 